\author{
Marquette University \\ e-Publications@Marquette
}

Civil and Environmental Engineering Faculty

Civil, Construction, and Environmental Research and Publications

Engineering, Department of

2015

\title{
The Role of Shrinkage Strains Causing Early-Age Cracking in Cast- in-Place Concrete Bridge Decks
}

Tayyebeh Mohammadi

Marquette University

Baolin Wan

Marquette University, baolin.wan@marquette.edu

Christopher M. Foley

Marquette University, christopher.foley@marquette.edu

Follow this and additional works at: https://epublications.marquette.edu/civengin_fac

Part of the Civil Engineering Commons, and the Construction Engineering and Management

Commons

\section{Recommended Citation}

Mohammadi, Tayyebeh; Wan, Baolin; and Foley, Christopher M., "The Role of Shrinkage Strains Causing Early-Age Cracking in Cast-in-Place Concrete Bridge Decks" (2015). Civil and Environmental Engineering Faculty Research and Publications. 138.

https://epublications.marquette.edu/civengin_fac/138 


\title{
The Role of Shrinkage Strains Causing Early-Age Cracking in Cast-in-Place Concrete Bridge Decks
}

\author{
Tayyebeh Mohammadi, Baolin Wan and Christopher M. Foley
}

Synopsis: Early-age cracking in cast-in-place reinforced concrete bridge decks is occurring more frequently now than three decades ago and principle factors that lead to early-age deck cracking are not fully understood. A finite element (FE) simulation methodology for assessing the role of shrinkage-induced strains in generating early-age bridge deck cracking is described. The simulations conducted indicate that drying shrinkage appears to be capable of causing transverse (and possibly longitudinal) bridge deck cracks as early as 9 to 11 days after bridge deck placement. The drying-shrinkage induced stresses would result in transverse cracking over interior pier supports in a typical bridge superstructure considered in the finite element simulations conducted.

Keywords: shrinkage; early age; cracking; concrete; bridge deck; finite element 
Tayyebeh Mohammadi is a structural engineer at Precast Engineering Company in Waukesha, Wisconsin. She received her MS in civil engineering at Ferdowsi University of Mashhad, Iran, and her Ph.D. at Marquette University, Milwaukee, WI.

$\mathrm{ACI}$ member of Baolin Wan is an associate professor in the Department of Civil, Construction and Environmental Engineering at Marquette University, Milwaukee, WI. He is an associate member of ACI Committee 440, FiberReinforced Polymer (FRP) Reinforcement. His research interests include use of FRP in structural members, numerical and experimental modeling of repaired and retrofitted structures, field testing and nondestructive evaluation of bridges, behavior of reinforced and prestressed concrete structural elements, and finite element analysis.

Christopher M. Foley is the Chair of and a professor in the Department of Civil, Construction and Environmental Engineering at Marquette University, Milwaukee, WI. His research interests include linear and nonlinear structural and finite element analysis, evolutionary algorithm applications in optimized structural design, structural steel building analysis and design, performance-based design of building and bridge structures, and seismic analysis and design.

\section{INTRODUCTION}

Early-age cracking in cast-in-place reinforced concrete bridge decks is occurring more frequently now than those in the bridges built before 1988 [1]. Cracking may form well in advance of a bridge being open to traffic, and sometimes it immediately follows construction [1-4]. Relatively recent surveys in the U.S. found that forty-two percent of bridge decks that show cracking crack within the first week after construction [5]. Crack mapping and structure surveys recently conducted in Wisconsin [6,7] indicate that early-age bridge deck cracking remains an issue. Cracks in bridge decks often grow wider than the limit recommended building design specifications [8]. ACI Code Section 10.6.3 to 10.6.7 [9] handle crack width indirectly by limiting the maximum bar spacing and bar covers for beams and slabs for a flexural crack width of $0.4 \mathrm{~mm}$. The ACI limit is based on the premise that the surface tension of water across a small opening (such as a crack) will provide an impenetrable barrier over the surface of that opening, thereby helping to prevent corrosion and further ingress of moisture. Bridge decks include trafficinduced loading, which may serve to force chloride solutions and other harmful chemicals into the cracks that form [10] resulting in potential deterioration of the steel reinforcement. The annual direct cost of corrosion in highway bridges in 2002 was $\$ 8.3$ billion, and indirect costs to users due to traffic delays and lost productivity is theorized to reach up to 10 times that amount [11]. Static and dynamic loading introduced by vehicles has been suggested as a cause of cracking in bridge decks [12]. Finite element simulation indicates an increased tendency for cracking when the tensile stresses developed under dead load and live load exceed 1.7 MPa [13]. It is possible that tensile stresses introduced by traffic loading superimposed with residual stresses resulting from construction-related phenomena may exceed the tensile strength of the concrete used in the bridge deck. This assumes that these additive stresses occur before creep would have a chance to reduce the residual stresses resulting from construction [1]. Loading applied to bridge decks can be classified into direct and indirect sources. Indirect loading results from volumetric change being prevented and can be caused by restraint arising from girders, shear studs, reinforcement, and abutments [1]; differing rates of moisture loss through the bridge deck thickness; and temperature gradients through the thickness of the concrete bridge deck and superstructure [2]. Direct loading can be thought of as that resulting from vehicles traveling on the bridge deck. The principle factors that lead to early-age deck cracking and their interaction are still not fully understood and the role of shrinkage-induced tensile strains remains to be quantified. The present manuscript outlines a finite element (FE) simulation methodology used for assessing the role of shrinkage-induced tensile strains that may lead to early-age cracking seen in modern bridge decks.

\section{RESEARCH SIGNIFICANCE}

Many newly constructed bridges have early-age concrete deck cracking. Such cracking causes durability problems and reduces the service life of a bridge deck and overlay. It is a complex problem and many variables have effects on it. Concrete shrinkage induces tensile stresses in the concrete deck, which may be larger than the tensile strength of the concrete in early age. Therefore, shrinkage is an important contributor to the early-age cracking. In this research, a typical two-span highway bridge with precast prestressed concrete girders and cast-in-place concrete decks was modeled by using finite element method to quantitatively study the effect of shrinkage on early-age concrete deck cracking. 


\section{CONTRIBUTORS TO EARLY-AGE CRACKING}

There are several dominant variables considered to contribute most to cracking in bridge decks and these have been grouped into five categories: material properties, site conditions, superstructure configuration, traffic, and age.

\section{Material Properties}

Cement type, cement content, slump, admixtures, w/c ratio, air content, Poisson's ratio, aggregate size/type, thermal diffusivity, use of epoxy coated rebar, and unconfined compressive strength have been considered to contribute to the tendency for cracking in bridge decks [14]. Higher unconfined compression strength is usually associated with increased cement content, increased cement paste volume, the quality of aggregate and size of aggregate, and higher hydration temperatures [1,2]. The properties of constitutive material of concrete can affect the cracking due to shrinkage. Use of shrinkage-compensating cement (i.e., Type K) since 1968 for bridge decks in Ohio has been reported to reduce shrinkage cracking [15].

\section{Site Conditions}

Researchers have noted a significant increase in cracking with increasing ambient temperature and guidelines for site temperatures at time of concrete placement have been proposed $[5,13,16]$. Some research found no relationship between relative humidity at the site and deck cracking in bridge decks [1], while others suggest that low humidity will increase evaporation rates and thus may increase plastic shrinkage magnitude [2]. An increase in wind velocity could increase the rate of evaporation. However, Schmitt and Darwin [1] found no relationship between wind velocity and deck cracking.

\section{Superstructure Characteristics}

Some research efforts suggest that decks on steel girders crack more frequently than those supported by concrete girders $[13,16]$. Other research suggests that cast-in-place concrete girders in particular have the best deck crack performance of all superstructure configurations [5]. A reduction in deck cracking with thickness increase has been reported and minimum deck thicknesses have been recommended $[5,17,18]$. There appears to be a correlation between top cover and cracking tendency [1,12]. Researchers have found that bar size, spacing, and distribution of reinforcement affect the cracking tendency $[1,2,5,12,17,18]$. Longitudinal bars are believed to help control deck stresses, and therefore increased amounts of longitudinal steel have been recommended $[5,16,18]$. Saadeghvaziri and Hadidi [2] found that any increase in longitudinal steel increases the tendency for cracking and PCA [16] suggests that splice locations act as an increase in bar diameter. An increase in the tendency for deck cracking has been seen when transverse steel is placed parallel to the deck skew [18]. It has been reported that skew angle can cause earlyage cracking resulting from adhesion resisting free shrinkage of the deck in the acute angle corners [19]. There appears to be no relationship between bridge superstructure span length and deck cracking $[1,2]$. Research suggests that flexibility of the bridge superstructure has no effect on the formation of transverse and other cracks $[16,13,18]$. However, finite element modeling illustrated that increasing the ratio of girder moment of inertia to deck moment of inertia (maintaining an equivalent composite section) can increase deck tensile stresses [2]. Research efforts have been undertaken to evaluate the effects of simple versus continuous bridge superstructures and simple configurations have been recommended to minimize cracking $[1,5,10]$. Construction practice using precast prestressed concrete girders with simple spans during deck placement and longer continuous spans for vehicle loading resistance may result in increased rotational demand at the ends of girders during deck placement and increased tendency for deck cracking. Finite element modeling suggests that increasing girder spacing will reduce cracking, due to the reduction of restraints (i.e. girders) at the base of the deck [2]. However, analysis of existing bridges has shown that there is a strong correlation between an increase in transverse beam spacing and an increase in the severity of deck cracking $[10,20]$. The restraint characteristics at the ends of girders in bridge superstructures has been characterized using generalized parameters and it has been recommended that substantial girder end restraint can result in a much higher probability of premature deck cracking [17]. Previous research suggests that girders with elastomeric bearing pads are more likely to crack [2].

\section{Traffic Loading and Construction Vintage}

A correlation between increased annual average daily traffic (AADT) and increased deck cracking has been suggested [1]. Furthermore, research has shown that bridges built before 1988 exhibit much less cracking than more recently built bridges [1]. This may be due to the higher cement contents in modern bridge decks generating greater magnitudes of shrinkage strains. It may also be due to the reduction in the particle sizes in cements used over the last several decades. The review of potential contributors to early-age bridge deck cracking revealed several parameters that could contribute to early-age bridge deck cracking. The authors have focused on what they feel to be 
the most important in taking an initial step toward analytically simulating the formation of early-age cracking in bridge deck systems. The conflicting research results found for many of the parameters described earlier also helped the authors narrow their consideration. The changing tensile strength and tensile stiffness of concrete with time is a very important parameter to consider. As concrete matures, its tensile strength is changing and it is important in assessing the tendency for early-age cracking. Secondly, shrinkage strains and the tendency for precast girders and their support configurations (e.g. diaphragm conditions at piers and abutments) to restrain free volumetric change within the cast-in-place deck system are critically important. The superstructure configuration including skew is important in any simulation conducted. As a result, it was decided to select an in-place bridge superstructure for finite element simulation.

\section{BRIDGE SUPERSTRUCTURE CONFIGURATION}

A bridge in Waupun, Wisconsin (Bridge B-20-134 on US Highway 151 overpass) was chosen as the target superstructure for simulation and evaluation. An overview photo of the continuous two-span superstructure is shown in Figure la. The girders are standard WisDOT precast prestressed girders, and the reinforcement is conventional epoxy-coated mild-steel reinforcing bars and low relaxation prestressing strands. Crack mapping that was part of a long term monitoring effort $[6,21]$ is shown in Figure $1 b$. This figure illustrates the extent of crack formation in the bridge deck found very soon after the bridge was open to traffic. The crack map serves as a guide to evaluating the finite element simulations to follow.

\section{FINITE ELEMENT MODEL}

The finite element (FE) simulation conducted in this research was done using the ANSYS finite element analysis system [22]. All structural simulations were conducted using linear-elastic analysis and elements that are standard within the software program. Figure 2 provides the WisDOT plan view for the superstructure and an overview plan of the created model used in this study. The creation of the bridge finite element model began with using Plane 182 elements to generate a planar model with the cross sectional ( $x-y$ plane) dimensions given in the Figure 3 . The bridge cross-section was then extruded (z-direction) into solid elements to create volumes representing the entire bridge. It should be noted that the skewed end conditions at the abutments were replaced with stepping in the deck model for easier extrusion to create the $3 \mathrm{D}$ model. To create the skew, each girder and associated deck/barrier was staggered by the amount $(1500 \mathrm{~mm} / 59.1 \mathrm{in}$.) to give an acceptable representation of the skew without any element connectivity issues occurred within the model (Figure 2). The concrete components were modeled using four-node isoparametric solid elements [22]. The bearing pads for the precast concrete girders centered under the girder ends were modeled using steel material. The major function of the bearing pads in this model is for modeling simplicity and to avoid the irregularity of the mesh at the supports. The analysis of this study focuses on the shrinkage strain in the bridge deck before first cracking, and the whole analysis is in linear elastic range. Therefore, the bearing pad modeling approach implemented has minimal (if any) effect on the stresses in the deck portion of the model. Steel instead of neoprene rubber was chosen to model the pads in order to simplify the model without significantly affecting the results. The typical precast girder and the solid model representation are given in Figure 4 . Concrete diaphragms or pilasters were modeled in the $300 \mathrm{~mm}(11.8 \mathrm{in}$.) space between the 5 sets of girders which connect the two spans. The diaphragms were initially modeled using the same shape and physical characteristics as the concrete girders as shown in Figure 5a. At the ends of the bridge girders and between girder spans, the concrete diaphragms were modeled using boundary/restraint conditions instead of the real diaphragms between girders. The restraints were applied on the exterior nodes on either side of the girder, excluding the nodes that were connected to either the deck or the steel plates (Figure 5b). In reality, the concrete diaphragms would be cast at an angle similar to that of the skew. In general, this may cause slightly increased stresses at the diaphragm locations. Steel channel diaphragms were modeled using diagonal bracing members (linear elastic spar/link/truss elements) whose crosssectional areas were designed to give the same flexural and shear stiffness present in the actual bridge [23]. Figure 4 shows a schematic representation of the bridge model cross-section at the location of the diaphragms. The girders

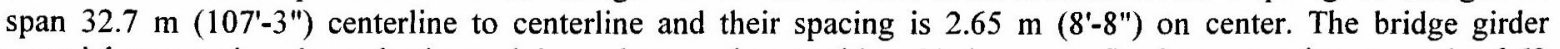
material was assigned an elastic modulus value consistent with a 28-day unconfined compressive strength of 62 $\mathrm{MPa}(9 \mathrm{ksi})$. A Poisson's ratio of 0.2 was selected for all concrete material [24]. The bridge deck was modeled using solid isoperimetric elements with three elements being used through the bridge deck thickness. The bridge deck was $200 \mathrm{~mm}(7.87 \mathrm{in}$.) thick and haunches between the deck soffit and girder top surface were omitted. The super elevation of the deck was omitted. The deck material included Poisson's ratio equal to 0.2 and a modulus of elasticity consistent with an unconfined compressive strength that was time dependent. 


\section{Shrinkage Strain}

Drying shrinkage of the concrete is defined as a decrease in volume under constant temperature due to loss of moisture. The following empirical model was used to establish transient values of drying shrinkage strain magnitude [25].

$$
\varepsilon_{s h}=-1.2 \cdot K_{v s} \cdot K_{h s} \cdot K_{f} \cdot K_{t d} \cdot \varepsilon_{u}
$$

For calculation of the parameters in equation (1), AASHTO 2010 has applied US units. Therefore in this section, US unit has been applied to obtain drying shrinkage strain magnitude. The parameter $\varepsilon_{s h}$ is the average strain due to shrinkage of the concrete based on AASHTO code. The concrete shrinkage development is a complex problem and there is no universally accepted model. The code equation is selected and its value is assumed to be the surface strain to simply the modeling. $\varepsilon_{u}$ is the ultimate shrinkage strain in the concrete (taken as 0.00048 ). The parameter $K_{v s}$ accounts for the effect of the volume-to-surface ratio of the concrete

$$
K_{v s}=1.45-0.13(V / S) \geq 1.0
$$

where: $V=$ volume of concrete; and $S=$ surface area of concrete. The volume to surface ratio for the deck in bridge B-20-134 used to establish this coefficient is $98.5 \mathrm{~mm}(3.876 \mathrm{in}$.) and the value of this coefficient was taken to be 1.0. The parameter $K_{h s}$ accounts for the fact that shrinkage varies with relative humidity and it may expressed as

$$
K_{h s}=2.0-0.014 \cdot H
$$

where $H=$ relative humidity (\%). Relative humidity data for the bridge deck's early life was not available and the authors were forced to make rational assumptions in this regard. The exterior surface of the bridge deck (top) was assumed to be at 70 percent relative humidity consistent with the bridge's location within Wisconsin [25]. Relative humidity measurements through the height of a bridge deck immediately adjacent to B-20-134 indicated that relative humidity values within the deck were higher than at the exposed surfaces $[7,21]$. Therefore, the center of the bridge deck was assumed to be at $80 \%$ relative humidity. The finite element model was developed with three elements across the thickness of the deck, and therefore $K_{h s}$ values were determined (linearly interpolated) at third points based on the top and center values. The magnitudes of the humidity coefficient computed using Equation (3) are given in Table 1 . The parameter $K_{f}$ takes into consideration the effect of concrete strength and can be expressed as

$$
K_{f}=\frac{5}{1+f_{c i}^{\prime}}
$$

where $f_{c i}^{\prime}$ is the specified unconfined compressive strength of concrete at the time of initial loading (ksi). If concrete age at time of initial loading is unknown at design time may be taken as $0.8 f_{c}^{\prime}$ [25]. Assuming that the 28-day strength of the deck concrete is $35 \mathrm{MPa}(5 \mathrm{ksi})$ [7], this coefficient is equal to 1.0 . The final parameter in the shrinkage strain model is the time-dependent factor $K_{t d}$

$$
K_{t d}=\frac{t}{61-4 f_{c i}^{\prime}+t}
$$

where $t$ is the maturity of the concrete (in days). Maturity is defined as the age of concrete between the end of curing and the time being considered. Assuming $f_{c i}^{\prime}$ of $80 \%$ of the 28 -day unconfined compression strength leads to the data in Table 2 for $\mathrm{K}_{\mathrm{td}}$ for a 14-day interval.

\section{Concrete Strength and Stiffness}

The objectives of the present FE simulation required the change in concrete unconfined compressive strength with time. The reported compressive strength data of bridge deck in Wan et al. [7] has been applied in the modeling. Figure 6 illustrates the compression strength model based on logarithmic interpolation for a 14-day interval. The modulus of elasticity is generally known to be related to the unconfined compression strength of the concrete. For moderate unconfined compression strengths, the modulus of elasticity, $E$, is often computed using the following [9]

$$
E=4700 \sqrt{f_{c}^{\prime}}
$$


where $E$ and $f_{c}^{\prime}$ are in MPa. The modulus of elasticity over the initial 14-day interval is shown in Table 2.

\section{Modeling Shrinkage Strain via Temperature Change}

Equation (1) provides an estimate of shrinkage strain magnitude at exposed concrete surfaces, but very little is known about values of shrinkage strain and variation through the bridge deck thickness. Some research suggests that the shrinkage strains can be analyzed as linear across the thickness of concrete with the top surface having the largest value of strain [5]. However, other research shows that drying strains (neglecting the effects of ambient thermal heating) within the deck will be equal at the exposed surfaces (top and bottom), thereby creating compression stresses at the center of the deck [26]. Assuming the concrete deck forms will remain in place for some finite amount of time during the concrete hardening, the linear strain distribution was assumed to simplify the analysis. To determine the slope of the strain distribution, the humidity at the center of the deck was obtained through field testing [21]. Because $K_{h s}$ is linearly dependent on humidity (Equation 3), the strain will be recalculated based on Equation (1). These two points of strain will help develop a shrinkage strain gradient throughout the top portion of the deck, and will be interpolated throughout the remaining thickness (Figure 7). The strain resulting from temperature change, $\Delta T$, is given by

$$
\varepsilon=\alpha \cdot \Delta T
$$

where: $\alpha$ is the coefficient of thermal expansion for the concrete material. It should be noted that the coefficient of thermal expansion for concrete materials is thought to range between $5 \times 10^{-6} / \operatorname{deg} F$ to $9 \times 10^{-6} / \operatorname{deg} F$. Target shrinkage strains from the model expressed using equation (1) are computed as presented in Figure 8 and a coefficient of thermal expansion and temperature change is defined to meet this shrinkage strain target. Table 3 contains temperature changes with time corresponding to the shrinkage strains computed using equation (7).

\section{FE Modeling Assumptions}

In creating a finite model to analyze the effects of concrete shrinkage, three significant assumptions were made. The first is that mild steel reinforcement in the bridge deck was neglected. It was deemed impractical to model the bonding relationship between rebar and concrete and the dimensionality of the rebar within the bridge deck and as such, the restraint due to steel rebars and their effects on concrete stresses resulting from their greater resistance to shrinkage-generated deformations in the surrounding concrete material cannot be captured in this FE analysis. Second, the self-weight of the bridge superstructure (girders and deck) was neglected. In general, when a bridge deck is placed, the concrete is in a viscous-fluid state, and formwork is required. Therefore, the girders will deflect under the self-weight of the deck. Thus, it has been assumed that the concrete deck deforms in a viscous-fluid state. In a viscous fluid state, no tensile stresses would be induced into the deck. Consideration of concrete placementsequence or placement-rate is omitted. The continuous slip-formed barriers were removed. Third, shrinkageinduced strains were introduced into the FE model via temperature loads. Negative temperature changes were used to generate shortening of the material fibers. Nodes in the FE model were selected as the temperature loading sites. In order to ensure that the temperature loading did not affect the girders (i.e. they are cast at different times), the girder material was given a coefficient of thermal expansion equal to zero. As a result, the precast girders did not shrink as a result of the temperature loading. A linear elastic analysis was run for the temperature gradient loading case. A script was written to conduct a separate FE simulation for each day with corresponding temperature changes and changes to the elastic material modulus. After each daily simulation is completed, the stresses developed are superimposed to give the total accumulated stress over the 14-day time period considered.

\section{Finite Element Analysis Results and Discussion}

Figure 9 illustrates the longitudinal stress contours in the bridge deck top surface due to the concrete shrinkage in the first day of its life in the simulation. The region of the bridge deck illustrated in the figure is a portion of the bridge deck from free-edge to free-edge and a longitudinal length equal to $9,600 \mathrm{~mm}\left(31^{\prime}-6^{\prime \prime}\right)$. The deck portion included in the contour is centered over the interior pier in the superstructure. There are nine points of interest labeled on the contour and these points will be used for reference with regard to stresses. Table 4 provides the numerical results for the bridge deck locations defined in Figure 10. Several observations can be made using the data in the table. First of all, there is an increase in stress on the bridge deck directly over girders. The data in the table for these locations corresponds to FE model nodes 1, 3, 5, 7, and 9 in Figure 9. It is clear that of the nine reference points selected, the five points directly over the girders have nearly $15 \%$ more stress than their four counterparts located in-between the 
girders. As mentioned before, mild steel reinforcement in the bridge deck was neglected in the finite element modeling. However, mild steel in the concrete deck (top and bottom in both directions) restrains the shrinkage of the concrete and affects the actual stresses in concrete. Therefore, the exclusion of the rebar in FE modeling may influence the value of $15 \%$ increase in the stress over the girders seen in the numerical simulation. Using the proposed shrinkage model in the finite element simulation of the first 14 days after casting illustrates the concrete will be susceptible to the largest tensile stresses during day three after casting (average stress of $0.329 \mathrm{MPa} / 48 \mathrm{psi}$ shown in Table 4). From the instant the deck is cast, the deck is continuously gaining strength, while at the same time becoming subjected to an increasing level of strain resulting from drying shrinkage as the concrete cures. Depending on the rate at which these two factors vary with time and interact with one another, it would seem logical that there would be a time in which the combination of increased rigidity and shrinkage strains would cause the largest amount of stress. From day 4 onward, there is a slight decrease in average daily stress moving toward day 14 . This rate of change is directly related to the shrinkage model. Although the analysis provides valuable insights into the deck behavior, the chosen shrinkage model in this study predicts a low maximum shrinkage after 14 days (0.00017) compared to the reported measured shrinkage by others (typically on the order of 0.00025 to 0.0005 ). The concrete used in this bridge deck gained a majority of its strength $(90 \%)$ in the first 14 days after casting. Normally, a majority of shrinkage strains in concrete develop in the first 100 days. Therefore, it makes sense that the maximum stresses due to shrinkage would occur early in the life of the bridge deck. This is not to say that additional stresses after day three do not play a larger role in deck cracking. However, the large early stresses seen in the finite element simulations suggest a need for special attention during the days immediately following casting. After concrete is set, its strength begins to increase continuously. At the same time, the tensile stress due to concrete shrinkage also increases continuously. For simplicity, the changes were lumped into a discrete time period (i.e., one day) in the analysis. In this model, the coefficient $K_{\mathrm{td}}$, Young's modulus and shrinkage varied each day as shown in Table 2. Therefore, the additional shrinkage developed over one-day period was calculated for each day of the first 14 days after concrete casting. Each simulation was run for the additional thermal loading relative to the previous day as shown in Table 3. The data in Table 4 is founded upon a summation of the stresses from fourteen individual simulations. The average daily stress is the average tensile stress that occurs at the 9 points across the bridge deck. The cumulative stress is the summation of average stresses up to and including the day in question. There are two common models used for assessing the cracking (tensile) strength of concrete [9]

$$
\begin{aligned}
& f_{r}=0.63 \sqrt{f_{c}^{\prime}} \\
& f_{t}=0.1 f_{c}^{\prime}
\end{aligned}
$$

The unconfined compression strength for the concrete deck material increases daily. As a result, the tensile strength of the concrete defined using both expressions above will change accordingly. Both of these tensile strength models were used to evaluate the tendency for the bridge deck concrete to crack at varying stages during the simulation. The information in Table 4 suggests that if $10 \%$ of the concrete's compressive strength was used to define the concrete's tensile strength, the concrete would crack after 9 days when cumulative tensile stress $(2.799 \mathrm{MPa} / 406 \mathrm{psi})$ is larger than of the concrete's tensile strength $(2.795 \mathrm{MPa} / 405 \mathrm{psi})$. If the modulus of rupture was used to characterize the tensile rupture strength of the concrete, it appears as though deck cracks would appear after 11 days. Therefore, the finite element simulations indicate that transverse cracking in the bridge deck over the interior pier could be expected 9 to 11 days after casting. The type and location of the cracks seen in the actual bridge (Figure 2) are consistent with the simulation results. Both the bridge deck and finite element models show significant transverse cracking over the interior pier.

While the purpose of the simulation discussed here was to evaluate the effects of shrinkage strains on creating stresses that cause early-age transverse cracking in bridge decks, it is also possible to analyze the stresses that would cause longitudinal cracking as well. Figure 10 provides a finite element stress contour of the transverse direction stresses in the same vicinity exhibited in Figure 9. There are several areas of peak stress. In each case, these areas are centered just to the right (or left) of a girder, and are elongated in the longitudinal direction. The diaphragms at the central pier and abutments were modeled with displacement restraint conditions in the transverse direction. The restraint directions were perpendicular to the girder longitudinal axes instead of to parallel to the skew and it appears as though the increased stress contours tend to be distorted in a longitudinal direction, as they follow the skewed shape of the bridge. Therefore, the modeling of the diaphragms likely caused a slight increase in stress at those locations. In general, the transverse stresses were found to be less than twice the magnitude of the longitudinal stresses. However, this does not imply that the transverse stresses are not important. The longitudinal and transverse stresses in combination could cause the deck to crack earlier than either would predict on their own. In analyzing the 
principle tensile stress over the center girder on the third day, a stress of $0.342 \mathrm{MPa}$ ( $50 \mathrm{psi}$ ) was found (compared to $0.332 \mathrm{MPa} / 48 \mathrm{psi}$ found in Table 4 for node 5 on day 3 ). Therefore, the principle tensile stress is approximately $3 \%$ larger than the longitudinal stress at that same location. However, it is clear that the longitudinal stresses (causing transverse cracking) are still the predominant stresses in the deck.

\section{CONCLUSIONS}

A model for the maximum shrinkage strain founded upon common parameters: volume-to-surface ratio of the concrete; the average humidity at the bridge location; time-varying unconfined compressive strength of the concrete; and the time over which the concrete cured was used as the basis for a finite element simulation of drying shrinkage behavior of a bridge deck. Although this model is able to predict the shrinkage strain at the early age of bridge decks by using the parameters which affect concrete shrinkage, the predicted maximum shrinkage strain value is lower than the general reported values of the maximum shrinkage strain at 14 days. The relative humidity of the concrete was guided by field hygrometer measurements at mid-thickness of the concrete and the magnitude of shrinkage strain was linearly interpolated throughout the remaining thickness at points that were convenient and consistent with the FE model developed. The shrinkage strain magnitudes were converted to equivalent temperature loadings suitable for implementation in finite element software. Fourteen independent linear elastic simulations were run and the results were superimposed. The finite element simulations conducted indicate that drying shrinkage appears to be capable of causing transverse bridge deck cracking at early stages in the life of the bridge deck. The simulations conducted indicate that cracking may occur as early as 9 to 11 days after bridge deck placement. Because the model used in this study is relatively simple (assuming linear variation of shrinkage strain and ignoring rebars), these numbers of days until first crack ( 9 to 11 days) will change for concrete materials with different shrinkage characteristics and for decks with double mats of rebar.

\section{ACKNOWLEDGEMENTS}

This research was funded through the Wisconsin Highway Research Program by the Wisconsin Department of Transportation and the Federal Highway Administration under Projects 0092-05-02 and 0092-09-96. The contents of this paper reflect the views of the authors who are responsible for the facts and accuracy of the data presented herein. The contents do not necessarily reflect the official views of the Wisconsin Department of Transportation or the Federal Highway Administration at the time of publication. The United States Government assumes no liability for its contents or use thereof. This report does not constitute a standard, specification or regulation.

\section{REFERENCES}

[1] Schmitt, T.R. and D. Darwin, D.W. 1995. Cracking in Concrete Bridge Decks, Report No. K-TRAN: KU-94-l, Final Report, Kansas Department of Transportation.

[2] Saadeghvaziri, M.A. and Hadidi, R. 2002. Cause and Control of Transverse Cracking in Bridge Decks, Report FHWA-NJ-2002-19, New Jersey Department of Transportation, Trenton, NJ, December, 188 pages.

[3] Saadeghvaziri, M.A. and Hadidi, R. 2005. Transverse Cracking of Concrete Bridge Decks: Effects of Design Factors, Journal of Bridge Engineering, Vol. 10, No. 5, American Society of Civil Engineers, Reston, VA, pp. 511519.

[4] Saadeghvaziri, M.A. and Hadidi, R. 2005. Transverse Cracking of Concrete Bridge Decks: State of the Art, Journal of Bridge Engineering, Vol. 10, No. 5, American Society of Civil Engineers, Reston, VA, pp. 503-510.

[5] Krauss, P.D. and Rogalla, E.A. 1996. Transverse Cracking in Newly Constructed Bridge Decks, NCHRP Report 380, Transportation Research Board, National Academies, Washington, DC.

[6] Martin, K.E. 2006. Impact of Environmental Effects on, and Condition Assessment of IBRC Bridge Decks in Wisconsin, MS Thesis, Marquette University, Milwaukee, WI, May.

[7] Wan, B., Foley, C.M., Komp, J. 2010. Concrete Cracking in New Bridge Decks and Overlays, Report SPR 0092-09-06, Wisconsin Highway Research Program Report WHRP 10-05, Wisconsin Department of Transportation, Madison, WI, March, 142 pages.

[8] Frosch, R.J., Blackman, D.T. and Radabaugh, R.D. 2002. Investigation of Bridge Deck Cracking in Various Bridge Superstructure Systems, FHWA/IN/JTRP-2002/25, Indiana Department of Transportation, Indianapolis, IN. 
[9] ACI 2005. Building Code Requirements for Reinforced Concrete, ACI 318-05, American Concrete Institute, Farmington Hills, MI.

[10] Keller, W.J. 2004. Effect of Environmental Conditions and Structural Design on Linear Cracking in Virginia Bridge Decks, MS Thesis, Virginia Polytechnic Institute and State University, Blacksburg, VA.

[11] Koch, G.H., Po, M., Broongers, H., Thompson, N.G., Virmani, Y.P., Prayer, J.H. 2002. Corrosion Costs and Preventative Strategies in the United States, Report FHWA-RD-01-156, Federal Highway Administration, Washington, DC.

[12] Ramey, G.E., Wolff, A.R., Wright, R.L. 1997. Structural Design Actions To Mitigate Bridge Deck Cracking, Practice Periodical on Structural Design \& Construction, Vol. 2, No. 3, American Society of Civil Engineers, Reston, VA, pp. 118-124.

[13] Cheng, T.T.H. and Johnston, D.W. 1985. Incidence Assessment of Transverse Cracking in Concrete Bridge Decks: Construction and Material Considerations, Report No. FHWA/NC/85-002 Vol. 1, North Carolina State University, Raleigh, NC, 232 pages.

[14] Schmitt, T.R. and D. Darwin, D.W. 1999. Effect of Material Properties on Cracking in Bridge Decks, Journal of Bridge Engineering, Vol. 4, No. 1, American Society of Civil Engineers, Reston, VA, pp. 8-13.

[15] Rubin, E. 2006. Crack-Free Bridge Decks, Shrinkage-compensating concrete may be the answer, Concrete Construction, January 2006, http://www.concreteconstruction.net/concrete-construction/crack-free-bridgedecks.aspx.

[16] PCA 1970. Durability of Concrete Bridge Decks, Portland Cement Association, Skokie, IL, 35 pages.

[17] French, C., Eppers, L., Le, Q., and Hajjar, J.F. 1999. Transverse cracking in concrete bridge decks, Transportation Research Record, No. 1688, National Academies, Washington, DC, pp. 21-29.

[18] Kochanski, T., Parry, J., Pruess, D., Schuchardt, L., Ziehr, J. 1990. Premature Cracking of Bridge Decks Study, Research Report, Wisconsin Department of Transportation, Madison, WI.

[19] Fu, G., Feng, J. Dimaria, J., and Zhuang, Y. 2007. Bridge Deck Corner Cracking on Skewed Structures, MDOT Report RC-1490, Michigan Department of Transportation.

[20] Buckler, J.G., Barton, F.W., Gomez, J.P., Massarelli, P.J., and McKeel, W.T. 2000. Effect of Girder Spacing on Bridge Deck Response, Research Report VTRC 01-R6, Virginia Transportation Research Council, Charlottesville, VA.

[21] Foley, C.M., Wan, B., Schneeman, C., Barnes, K., Komp, J., Liu, J, Smith, A. 2010. In-Situ Monitoring and Testing of IBRC Bridges in Wisconsin, Report SPR 0092-05-02, Wisconsin Highway Research Program Report WHRP 10-09, Wisconsin Department of Transportation, Madison, WI, June, 226 pages.

[22] ANSYS 2010. ANSYS Finite Element Analysis System, Release 13.0.

[23] Komp, J. 2009. Evaluation Of Premature Cracking In Concrete Bridge Decks Using Finite Element Analysis, MS Thesis, Marquette University, Milwaukee, WI.

[24] Kachlakev, D., Miller, T., Yim, S., Chanasawat, K., Potisuk, T. 2001. Finite Element Modeling of Reinforced Concrete Structures Strengthened with FRP Laminates, Final Report SPR 316, Oregon Department of Transportation Research Group, Salem, OR, 99 pages.

[25] AASHTO 2010. AASHTO LRFD Bridge Design Specifications, 3rd Edition, 2010 Interim Revisions, American Association of State Highway and Transportation Officials, Washington D.C. 
[26] Tadros, M.K., and Al-Omaishi, N. 2003. Prestress Losses in Pretensioned High-Strength Concrete Bridge Girders, NCHRP Report 496, National Cooperative Highway Research Program, Transportation Research Board, National Academies, Washington, DC. 
Mohammadi et al.

Table 1- Humidity coefficient through deck thickness

\begin{tabular}{c|c}
\hline Location & $K_{h s}$ \\
\hline Top of Deck & 1.02 \\
1/3 Down & 0.927 \\
2/3 Down & 0.833 \\
Bottom of Deck & 0.74 \\
\hline
\end{tabular}

Table 2-Time dependent coefficient, Young's modules and shrinkage of co

\begin{tabular}{c|c|c|c}
\hline Time (days) & $K_{t d}$ & $\begin{array}{c}E \\
\mathrm{MPa}(\mathrm{ksi})\end{array}$ & $\varepsilon_{s h}$ \\
\hline 1 & 0.022 & $20403(2959)$ & 0.0000152 \\
3 & 0.042 & $21696(3147)$ & 0.0000290 \\
4 & 0.062 & $22490(3262)$ & 0.0000429 \\
5 & 0.082 & $23071(3346)$ & 0.0000567 \\
6 & 0.100 & $23531(3413)$ & 0.0000691 \\
7 & 0.118 & $23915(3469)$ & 0.0000816 \\
8 & 0.135 & $24244(3516)$ & 0.0000933 \\
9 & 0.151 & $24533(3558)$ & 0.0001044 \\
10 & 0.167 & $24790(3559)$ & 0.0001155 \\
11 & 0.182 & $25023(3629)$ & 0.0001258 \\
12 & 0.196 & $25235(3660)$ & 0.0001355 \\
13 & 0.210 & $25430(3688)$ & 0.0001452 \\
14 & 0.224 & $25611(3715)$ & 0.0001549 \\
& 0.237 & $25780(3739)$ & 0.0001639 \\
\hline
\end{tabular}


The Role of Shrinkage Strains Causing Early-Age Cracking in Cast-in-Place Concrete Bridge Decks

Table 3-Temperature change gradient through bridge deck

\begin{tabular}{c|c|c|c|c}
\hline \multirow{2}{*}{$\begin{array}{c}\text { Time } \\
\text { (days) }\end{array}$} & \multicolumn{5}{|c}{$\Delta T:{ }^{\circ} \mathrm{F}\left({ }^{\circ} \mathrm{C}\right)$} \\
\cline { 2 - 5 } & Top Surface & $1 / 3$ Down & $2 / 3$ Down & Bottom Surface \\
\hline 1 & $2.119(1.177)$ & $1.925(1.069)$ & $1.731(0.962)$ & $1.537(0.854)$ \\
2 & $4.153(2.307)$ & $3.773(2.096)$ & $3.393(1.885)$ & $3.013(1.674)$ \\
3 & $6.106(3.392)$ & $5.548(3.082)$ & $4.990(2.772)$ & $4.431(2.462)$ \\
4 & $7.985(4.436)$ & $7.253(4.029)$ & $6.527(3.626)$ & $5.794(3.219)$ \\
5 & $9.797(5.443)$ & $8.900(4.944)$ & $8.003(4.446)$ & $7.106(3.948)$ \\
6 & $11.535(6.408)$ & $10.480(5.822)$ & $9.424(5.236)$ & $8.369(4.649)$ \\
7 & $13.213(7.341)$ & $12.005(6.669)$ & $10.797(5.998)$ & $9.589(5.327)$ \\
8 & $14.835(8.242)$ & $13.475(7.486)$ & $12.121(6.734)$ & $12.524(6.958)$ \\
9 & $16.397(9.109)$ & $14.896(8.276)$ & $13.396(7.442)$ & $11.895(6.608)$ \\
10 & $17.903(9.946)$ & $16.263(9.035)$ & $14.628(8.127)$ & $12.987(7.215)$ \\
11 & $19.361(10.756)$ & $17.586(9.770)$ & $15.817(8.787)$ & $14.042(7.801)$ \\
12 & $20.764(11.536)$ & $18.867(10.482)$ & $16.964(9.424)$ & $15.067(8.371)$ \\
13 & $22.131(12.295)$ & $20.106(11.170)$ & $18.08(10.044)$ & $16.055(8.919)$ \\
14 & $23.448(13.027)$ & $21.301(11.834)$ & $19.154(10.641)$ & $17.013(9.452)$ \\
\hline
\end{tabular}


Table 4-Longitudinal bridge deck stress variation with location: $\mathrm{MPa}$ (psi)

\begin{tabular}{|c|c|c|c|c|c|c|c|c|c|c|c|c|c|c|}
\hline \multirow{2}{*}{$\begin{array}{c}\text { Node } \\
\text { Location }\end{array}$} & \multicolumn{14}{|c|}{ 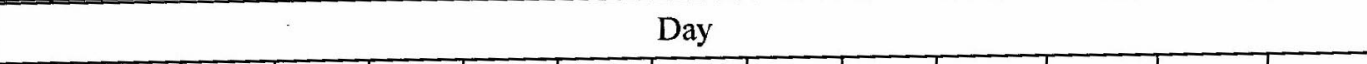 } \\
\hline & 1 & 2 & 3 & 4 & 5 & 6 & 7 & 8 & 9 & 10 & 11 & 12 & 13 & 14 \\
\hline 1 & $\begin{array}{c}0.368 \\
(53)\end{array}$ & $\begin{array}{c}0.375 \\
(54)\end{array}$ & $\begin{array}{c}0.376 \\
(55)\end{array}$ & $\begin{array}{c}0.367 \\
(53)\end{array}$ & $\begin{array}{c}0.360 \\
(52)\end{array}$ & $\begin{array}{c}0.352 \\
(51)\end{array}$ & $\begin{array}{c}0.344 \\
(50)\end{array}$ & $\begin{array}{c}0.335 \\
(49)\end{array}$ & $\begin{array}{c}0.326 \\
(47)\end{array}$ & $\begin{array}{c}0.318 \\
(46)\end{array}$ & $\begin{array}{c}0.310 \\
(45)\end{array}$ & $\begin{array}{c}0.300 \\
(44)\end{array}$ & $\begin{array}{c}0.294 \\
(43)\end{array}$ & $\begin{array}{c}0.286 \\
(41)\end{array}$ \\
\hline 2 & $\begin{array}{c}0.301 \\
(44)\end{array}$ & $\begin{array}{c}0.305 \\
(44)\end{array}$ & $\begin{array}{c}0.306 \\
(44)\end{array}$ & $\begin{array}{c}0.298 \\
(43)\end{array}$ & $\begin{array}{c}0.292 \\
(42)\end{array}$ & $\begin{array}{c}0.285 \\
(41)\end{array}$ & $\begin{array}{c}0.278 \\
(40)\end{array}$ & $\begin{array}{c}0.271 \\
(39)\end{array}$ & $\begin{array}{c}0.264 \\
(38)\end{array}$ & $\begin{array}{c}0.257 \\
(37)\end{array}$ & $\begin{array}{c}0.251 \\
(36)\end{array}$ & $\begin{array}{c}0.243 \\
(35)\end{array}$ & $\begin{array}{c}0.238 \\
(35)\end{array}$ & $\begin{array}{c}0.231 \\
(34)\end{array}$ \\
\hline 3 & $\begin{array}{c}0.329 \\
(48)\end{array}$ & $\begin{array}{c}0.333 \\
(48)\end{array}$ & $\begin{array}{c}0.334 \\
(48)\end{array}$ & $\begin{array}{c}0.325 \\
(47)\end{array}$ & $\begin{array}{c}0.318 \\
(46)\end{array}$ & $\begin{array}{c}0.311 \\
(45)\end{array}$ & $\begin{array}{c}0.303 \\
(44)\end{array}$ & $\begin{array}{c}0.295 \\
(43)\end{array}$ & $\begin{array}{c}0.288 \\
(42)\end{array}$ & $\begin{array}{c}0.280 \\
(41)\end{array}$ & $\begin{array}{c}0.273 \\
(40)\end{array}$ & $\begin{array}{c}0.264 \\
(38)\end{array}$ & $\begin{array}{c}0.259 \\
(34)\end{array}$ & $\begin{array}{c}0.251 \\
(36)\end{array}$ \\
\hline 4 & $\begin{array}{c}0.297 \\
(43)\end{array}$ & $\begin{array}{c}0.301 \\
(44)\end{array}$ & $\begin{array}{c}0.302 \\
(44)\end{array}$ & $\begin{array}{c}0.294 \\
(43)\end{array}$ & $\begin{array}{c}0.287 \\
(42)\end{array}$ & $\begin{array}{c}0.280 \\
(41)\end{array}$ & $\begin{array}{c}0.273 \\
(40)\end{array}$ & $\begin{array}{c}0.266 \\
(39)\end{array}$ & $\begin{array}{c}0.260 \\
(38)\end{array}$ & $\begin{array}{c}0.253 \\
(37)\end{array}$ & $\begin{array}{c}0.246 \\
(36)\end{array}$ & $\begin{array}{c}0.238 \\
(35)\end{array}$ & $\begin{array}{c}0.234 \\
(34)\end{array}$ & $\begin{array}{c}0.227 \\
(33)\end{array}$ \\
\hline 5 & $\begin{array}{c}0.327 \\
(47)\end{array}$ & $\begin{array}{c}0.331 \\
(48)\end{array}$ & $\begin{array}{c}0.332 \\
(48)\end{array}$ & $\begin{array}{c}0.323 \\
(47)\end{array}$ & $\begin{array}{c}0.316 \\
(46)\end{array}$ & $\begin{array}{c}0.308 \\
(45)\end{array}$ & $\begin{array}{c}0.301 \\
(44)\end{array}$ & $\begin{array}{c}0.293 \\
(42)\end{array}$ & $\begin{array}{c}0.285 \\
(41)\end{array}$ & $\begin{array}{c}0.278 \\
(40)\end{array}$ & $\begin{array}{c}0.271 \\
(39)\end{array}$ & $\begin{array}{c}0.262 \\
(38)\end{array}$ & $\begin{array}{c}0.257 \\
(37)\end{array}$ & $\begin{array}{c}0.249 \\
(36)\end{array}$ \\
\hline 6 & $\begin{array}{c}0.297 \\
(43)\end{array}$ & $\begin{array}{c}0.301 \\
(44)\end{array}$ & $\begin{array}{c}0.302 \\
(44)\end{array}$ & $\begin{array}{c}0.294 \\
(43)\end{array}$ & $\begin{array}{c}0.287 \\
(42)\end{array}$ & $\begin{array}{c}0.280 \\
(41)\end{array}$ & $\begin{array}{c}0.273 \\
(40)\end{array}$ & $\begin{array}{c}0.266 \\
(39)\end{array}$ & $\begin{array}{c}0.260 \\
(38)\end{array}$ & $\begin{array}{c}0.253 \\
(37)\end{array}$ & $\begin{array}{c}0.246 \\
(36)\end{array}$ & $\begin{array}{c}0.238 \\
(35)\end{array}$ & $\begin{array}{c}0.234 \\
(34)\end{array}$ & $\begin{array}{c}0.227 \\
(33)\end{array}$ \\
\hline 7 & $\begin{array}{c}0.329 \\
(48)\end{array}$ & $\begin{array}{c}0.334 \\
(48)\end{array}$ & $\begin{array}{c}0.334 \\
(48)\end{array}$ & $\begin{array}{c}0.326 \\
(47)\end{array}$ & $\begin{array}{c}0.319 \\
(46)\end{array}$ & $\begin{array}{c}0.312 \\
(45)\end{array}$ & $\begin{array}{c}0.304 \\
(44)\end{array}$ & $\begin{array}{c}0.296 \\
(43)\end{array}$ & $\begin{array}{c}0.289 \\
(42)\end{array}$ & $\begin{array}{c}0.281 \\
(41)\end{array}$ & $\begin{array}{c}0.274 \\
(40)\end{array}$ & $\begin{array}{c}0.265 \\
(38)\end{array}$ & $\begin{array}{c}0.260 \\
(38)\end{array}$ & $\begin{array}{c}0.252 \\
(37)\end{array}$ \\
\hline 8 & $\begin{array}{c}0.301 \\
(44)\end{array}$ & $\begin{array}{c}0.305 \\
(44)\end{array}$ & $\begin{array}{c}0.305 \\
(44)\end{array}$ & $\begin{array}{c}0.298 \\
(43)\end{array}$ & $\begin{array}{c}0.292 \\
(42)\end{array}$ & $\begin{array}{c}0.285 \\
(41)\end{array}$ & $\begin{array}{c}0.278 \\
(40)\end{array}$ & $\begin{array}{c}0.271 \\
(39)\end{array}$ & $\begin{array}{c}0.264 \\
(38)\end{array}$ & $\begin{array}{c}0.257 \\
(37)\end{array}$ & $\begin{array}{c}0.251 \\
(36)\end{array}$ & $\begin{array}{c}0.243 \\
(35)\end{array}$ & $\begin{array}{c}0.238 \\
(35)\end{array}$ & $\begin{array}{c}0.231 \\
(34)\end{array}$ \\
\hline 9 & $\begin{array}{c}0.368 \\
(53)\end{array}$ & $\begin{array}{c}0.375 \\
(54)\end{array}$ & $\begin{array}{c}0.376 \\
(55)\end{array}$ & $\begin{array}{c}0.368 \\
(53)\end{array}$ & $\begin{array}{c}0.360 \\
(52)\end{array}$ & $\begin{array}{c}0.352 \\
(51)\end{array}$ & $\begin{array}{c}0.345 \\
(50)\end{array}$ & $\begin{array}{c}0.336 \\
(49)\end{array}$ & $\begin{array}{c}0.327 \\
(47)\end{array}$ & $\begin{array}{c}0.319 \\
(46)\end{array}$ & $\begin{array}{c}0.311 \\
(45) \\
\end{array}$ & $\begin{array}{c}0.301 \\
(44) \\
\end{array}$ & $\begin{array}{c}0.295 \\
(43)\end{array}$ & $\begin{array}{c}0.287 \\
(42) \\
\end{array}$ \\
\hline $\begin{array}{c}\text { Average } \\
\text { Stress }\end{array}$ & $\begin{array}{c}0.324 \\
(47)\end{array}$ & $\begin{array}{c}0.328 \\
(48)\end{array}$ & $\begin{array}{c}0.329 \\
(48)\end{array}$ & $\begin{array}{c}0.321 \\
(47)\end{array}$ & $\begin{array}{c}0.315 \\
(46)\end{array}$ & $\begin{array}{c}0.307 \\
(45)\end{array}$ & $\begin{array}{c}0.300 \\
(44)\end{array}$ & $\begin{array}{c}0.292 \\
(42)\end{array}$ & $\begin{array}{c}0.285 \\
(41)\end{array}$ & $\begin{array}{c}0.277 \\
(40)\end{array}$ & $\begin{array}{c}0.272 \\
(39)\end{array}$ & $\begin{array}{c}0.261 \\
(38)\end{array}$ & $\begin{array}{c}0.256 \\
(37) \\
\end{array}$ & $\begin{array}{c}0.249 \\
(36)\end{array}$ \\
\hline $\begin{array}{c}\text { Cum. Avg. } \\
\text { Stress }\end{array}$ & $\begin{array}{c}0.324 \\
(47)\end{array}$ & $\begin{array}{c}0.653 \\
(95)\end{array}$ & $\begin{array}{l}0.979 \\
(142)\end{array}$ & $\begin{array}{l}1.300 \\
(189)\end{array}$ & $\begin{array}{l}1.615 \\
(234)\end{array}$ & $\begin{array}{l}1.922 \\
(279)\end{array}$ & $\begin{array}{l}2.222 \\
(322)\end{array}$ & $\begin{array}{l}2.514 \\
(365)\end{array}$ & $\begin{array}{l}2.799 \\
(406)\end{array}$ & $\begin{array}{l}3.076 \\
(446)\end{array}$ & $\begin{array}{l}3.348 \\
(486) \\
\end{array}$ & $\begin{array}{l}3.609 \\
(523) \\
\end{array}$ & $\begin{array}{l}3.865 \\
(561)\end{array}$ & $\begin{array}{l}4.114 \\
(597) \\
\end{array}$ \\
\hline $0.63 \sqrt{f_{c}^{\prime}}$ & $\begin{array}{l}2.684 \\
(389)\end{array}$ & $\begin{array}{l}2.855 \\
(414)\end{array}$ & $\begin{array}{l}2.959 \\
(429)\end{array}$ & $\begin{array}{l}3.036 \\
(440)\end{array}$ & $\begin{array}{l}3.096 \\
(449)\end{array}$ & $\begin{array}{l}3.147 \\
(456)\end{array}$ & $\begin{array}{l}3.190 \\
(463)\end{array}$ & $\begin{array}{l}3.228 \\
(468)\end{array}$ & $\begin{array}{l}3.262 \\
(473)\end{array}$ & $\begin{array}{l}3.292 \\
(477)\end{array}$ & $\begin{array}{l}3.320 \\
(482)\end{array}$ & $\begin{array}{l}3.346 \\
(485)\end{array}$ & - & - \\
\hline $0.1 f_{c}^{\prime}$ & $\begin{array}{l}1.858 \\
(269)\end{array}$ & $\begin{array}{l}2.101 \\
(305)\end{array}$ & $\begin{array}{l}2.258 \\
(327)\end{array}$ & $\begin{array}{l}2.376 \\
(345)\end{array}$ & $\begin{array}{l}2.472 \\
(359)\end{array}$ & $\begin{array}{l}2.553 \\
(370)\end{array}$ & $\begin{array}{l}2.624 \\
(381)\end{array}$ & $\begin{array}{l}2.687 \\
(390)\end{array}$ & $\begin{array}{l}2.795 \\
(405)\end{array}$ & $\left\{\begin{array}{l}3.113 \\
(452)\end{array}\right.$ & - & - & - & - \\
\hline
\end{tabular}


Mohammadi et al.
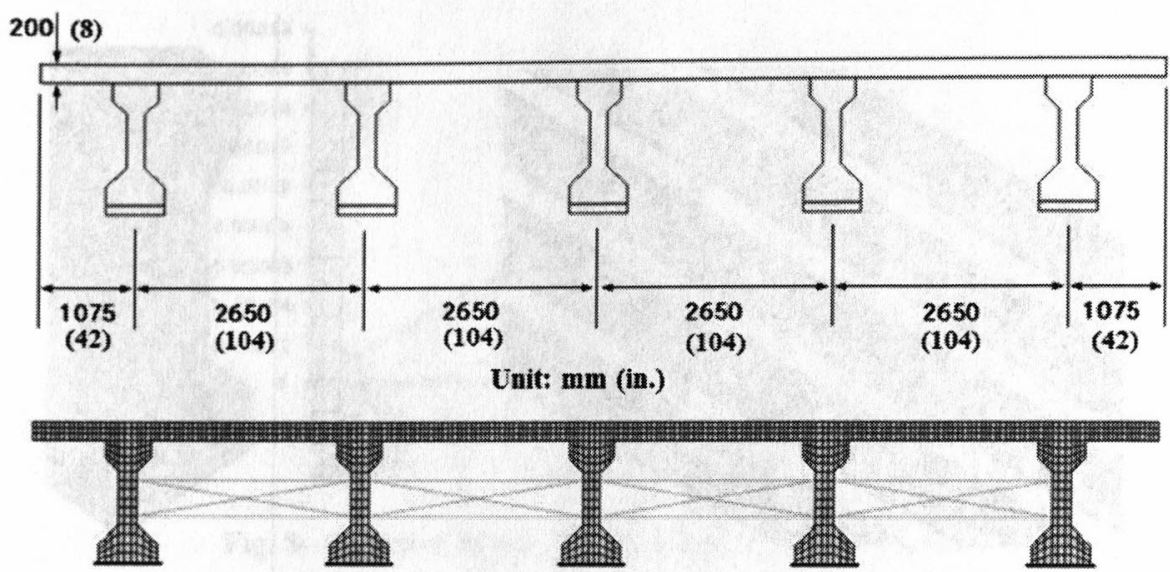

Fig.3-Bridge B-20-134 cross section.

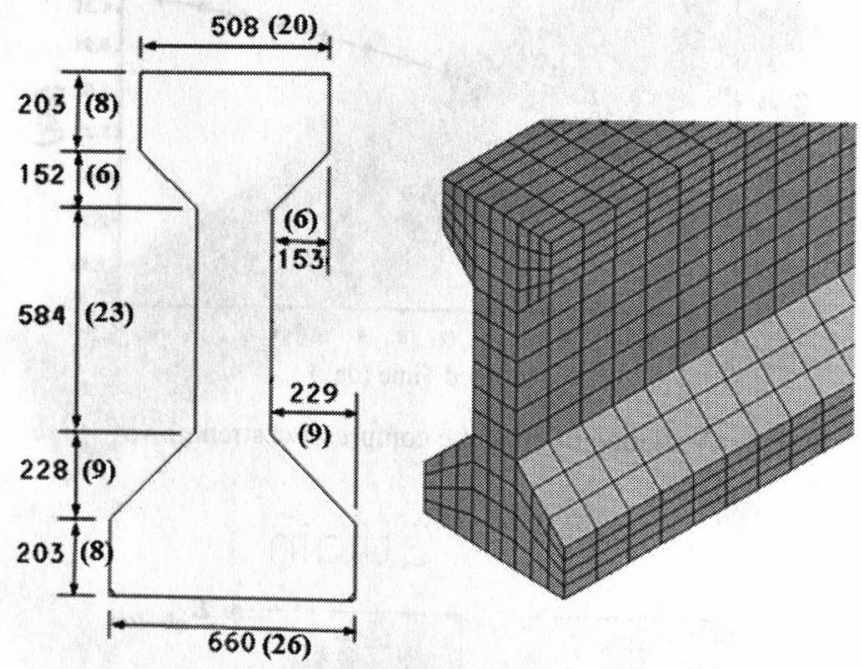

Unit: $\mathbf{m m}$ (in.)

Fig. 4-Modeling of standard WisDOT deep precast girder. 


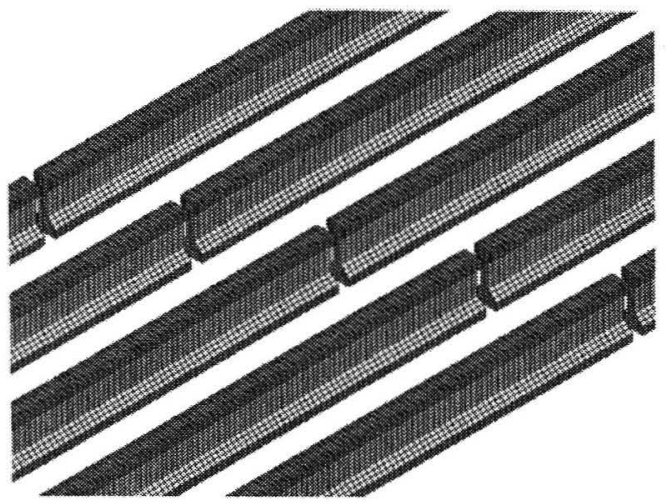

(a)

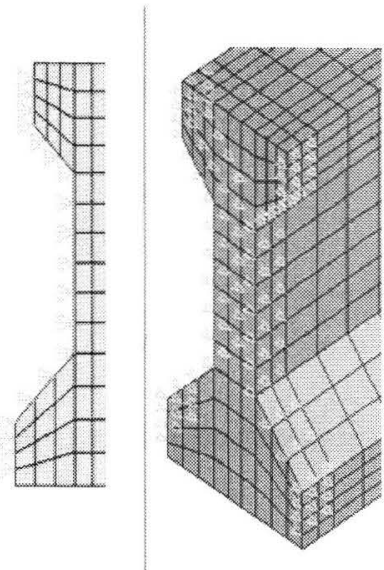

(b)

Fig. 5-Modeling approach: (a) concrete diaphragms at interior, (b) end diaphragm restraints.

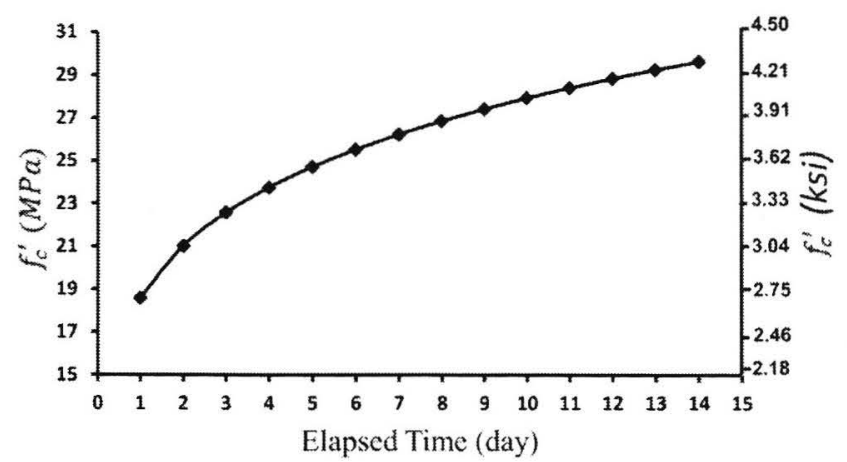

Fig. 6-Variation of concrete compressive strength with time.
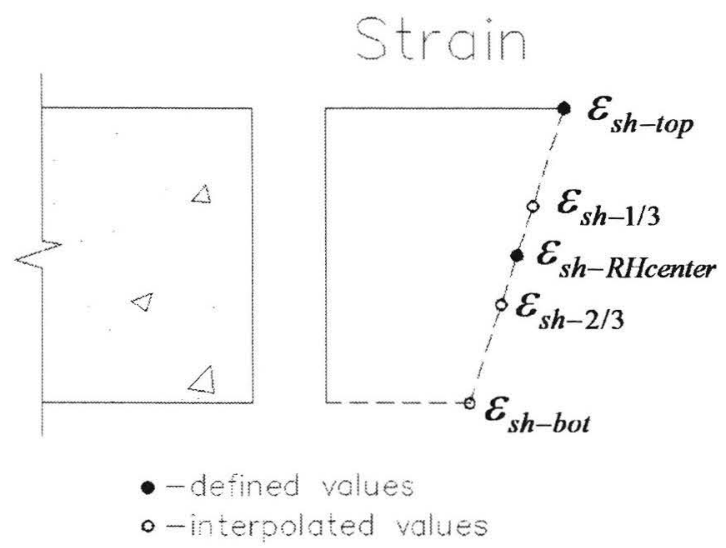

Fig. 7-Shrinkage strain distribution throughout the deck. 
Mohammadi et al.

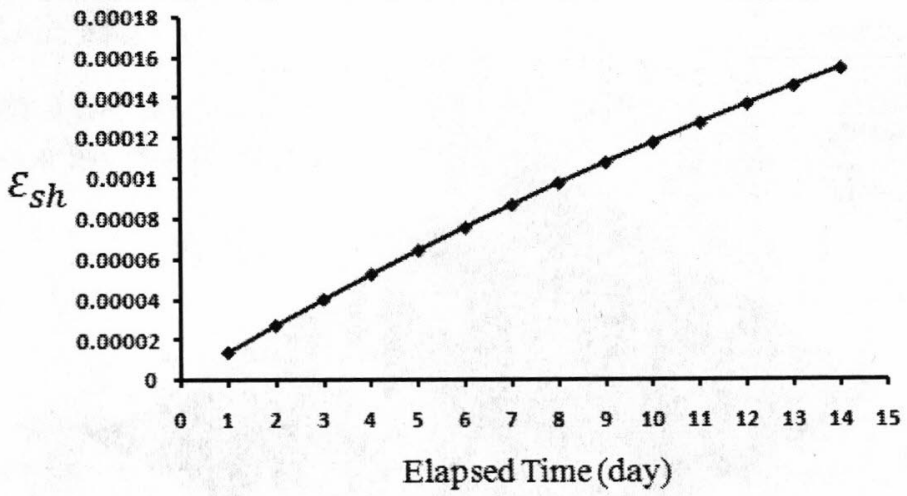

Fig. 8-Variation of concrete shrinkage strain with time.

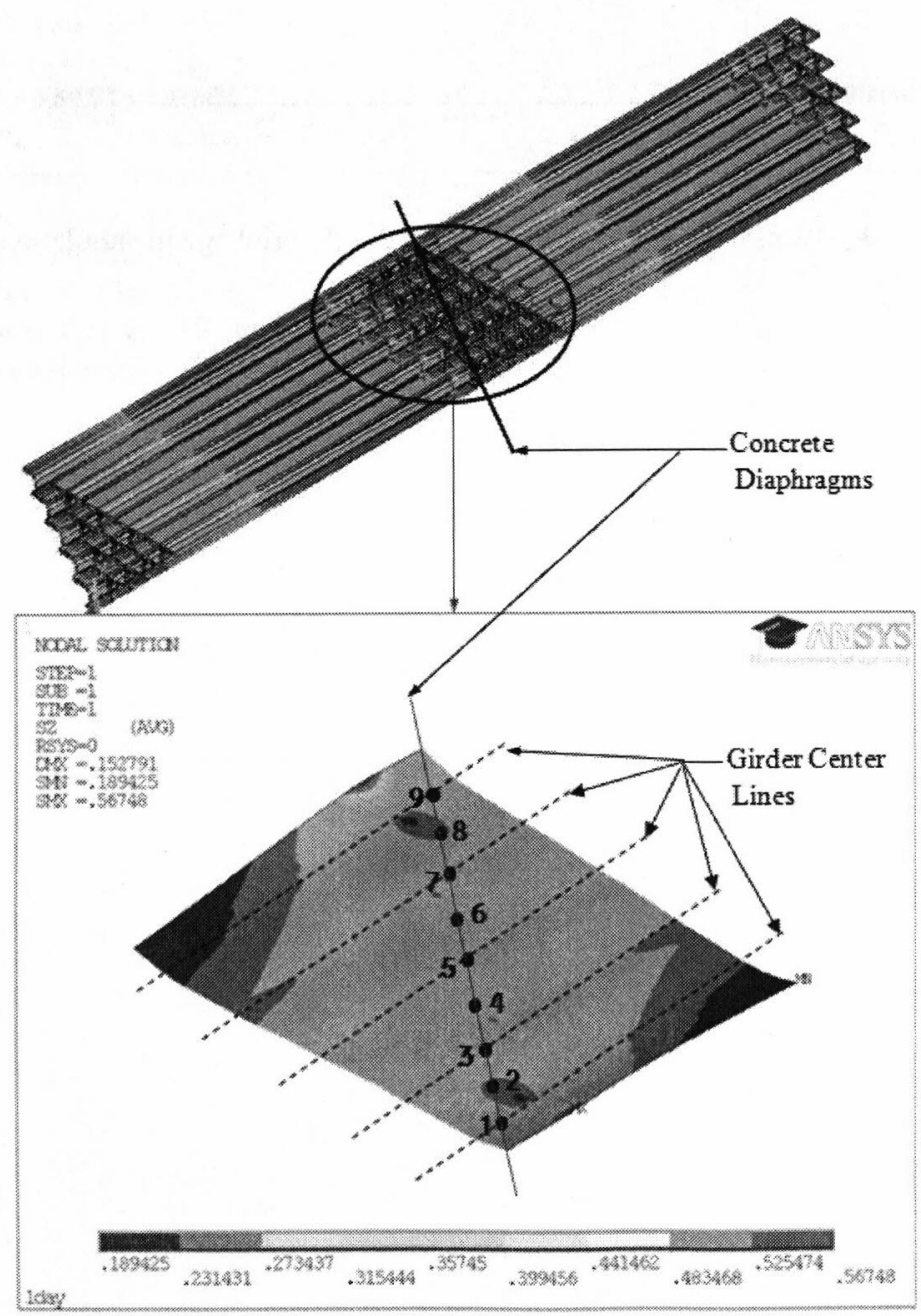

Fig. 9-Longitudinal stress contour due to day 1 shrinkage in simulation. 
The Role of Shrinkage Strains Causing Early-Age Cracking in Cast-in-Place Concrete Bridge Decks

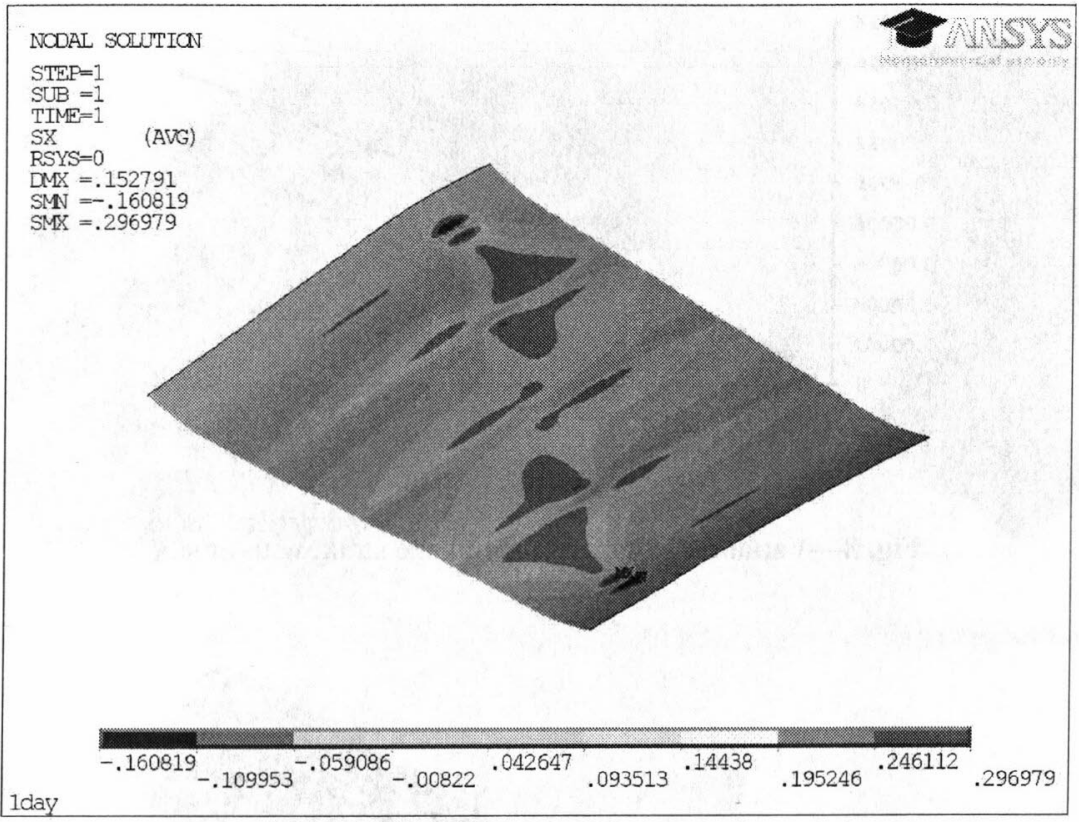

Fig. 10 - Transverse stress contour due to day 1 shrinkage in simulation. 